University of Nebraska - Lincoln

DigitalCommons@University of Nebraska - Lincoln

Agronomy \& Horticulture -- Faculty Publications

Agronomy and Horticulture Department

1969

Engineering for Higher Yields

Yoshiaki Ishizuka

Hokkaido University, Sapporo, Japan

Follow this and additional works at: https://digitalcommons.unl.edu/agronomyfacpub

Part of the Plant Sciences Commons

Ishizuka, Yoshiaki, "Engineering for Higher Yields" (1969). Agronomy \& Horticulture -- Faculty Publications. 188.

https://digitalcommons.unl.edu/agronomyfacpub/188

This Article is brought to you for free and open access by the Agronomy and Horticulture Department at DigitalCommons@University of Nebraska - Lincoln. It has been accepted for inclusion in Agronomy \& Horticulture -Faculty Publications by an authorized administrator of DigitalCommons@University of Nebraska - Lincoln. 
Published in Physiological Aspects of Crop Yield: Proceedings of a symposium sponsored by the University of Nebraska, the American Society of Agronomy, and the Crop Science Society of America, and held at the University of Nebraska, Lincoln, Nebr., January 20-24, 1969. Edited by Jerry D. Eastin, F. A. Haskins, C. Y. Sullivan, C. H. M. Van Bavel, and Richard C. Dinauer (Madison, Wisconsin: American Society of Agronomy \& Crop Science Society of America, 1969). Copyright (C) 1969 American Society of Agronomy \& Crop Science Society of America. Used by permission. 


\title{
2
}

\section{Engineering for Higher Yields}

\author{
YOSHIAKI ISHIZUKA \\ Hokkaido University \\ Sapporo, Japan
}

\section{INTRODUCTION}

It was difficult for me to understand the meaning of "engineering" as used in the title of my speech. I asked Dr. Haskins who told me that the term engineering is used here because one traditional role of the engineer has been the application of scientific principles in the solution of practical problems, and that in this case we want to consider the application of biological principles in both past and future increases in crop yield. Accordingly, I intend to express my thoughts on this problem, and to ask your suggestions for obtaining higher and better yields in the future. As I belong to an Asian nation, where rice is the main food, I will use the rice plant (Oryza sativa L.) as an example to illustrate my ideas. However, I am convinced that the principles which can be applied to the rice plant, will also apply to other crops such as wheat [Triticum (aestivum L.) sp.] or corn (Zea mays L.).

\section{CHANGES IN RICE YIELD FROM 1000 A.D.}

The yield of brown rice in 900 A.D. was approximately 1 ton/ha (Table 2-1) and in 1885, the year of the Meiji Revolution, which was the dawn of modern Japan, the yield was about 2 tons/ha. Thus, it took about 1,000 years (from 900 A.D. to 1885) to double the yield, while it took less than 100 years, from 1885 up to the present time to redouble the yield. The main reason for the relatively rapid improvement in rice yield since the turn of the century (Fig. 2-1) is the intelligent integration of the following factors:

1) New varieties developed by scientific and systematic breeding.

2) Progress of cultivation techniques.

3) Use of chemical fertilizers, especially nitrogen.

4) Use of fungicides, insecticides and herbicides.

5) Improvement of soils.

Use of these production techniques may seem only common sense to 
Table $2-1-$ Change of rice yield (metric tons) in Japan since 800 A.D.

\begin{tabular}{|c|c|c|c|c|}
\hline Chronicle & $\begin{array}{l}\text { Acreage of } \\
\text { rice flelds, } \\
\text { million ha }\end{array}$ & $\begin{array}{l}\text { Total yield, } \\
\text { million } \\
\text { tons }\end{array}$ & $\begin{array}{l}\text { Yield, } \\
\text { tons/ha }\end{array}$ & Remarks \\
\hline $800-900$ & 105 & 106 & 1.01 & \\
\hline 1550 & $105-120$ & 180 & 1.65 & \\
\hline 1720 & 164 & 315 & 1.92 & $\begin{array}{l}\text { Systematic introduction } \\
\text { of irrigation systems }\end{array}$ \\
\hline 1840 & 156 & 300 & 1.92 & \\
\hline $1878-1887$ & 258 & 477 & 1.85 & \\
\hline $1908-1917$ & 300 & 794 & 2.64 & $\begin{array}{l}\text { Scientific varietal } \\
\text { Improvement (breeding) }\end{array}$ \\
\hline $1938-1942$ & 318 & 953 & 2.99 & $\begin{array}{l}\text { Beginning of use of } \\
\text { chemfical fertllizers }\end{array}$ \\
\hline $1956-1965$ & 313 & 1,238 & 3.95 & $\begin{array}{l}\text { Heavy use of nitrogen } \\
\text { integrated techniques } \\
\text { including fungicides, } \\
\text { herbicides, etc. }\end{array}$ \\
\hline
\end{tabular}

agronomists, but it is useful to keep the indicated factors in mind because they are fundamental toward obtaining higher crop yields.

\section{A BLUEPRINT TO OBTAIN 6 TONS/HA OF BROWN RICE}

Though the same variety and enough fertilizers are used, there still exists a great difference in rice yield among farms-even in the same region. If, within a region, the lower yields could be brought up to the levels obtained by good farmers, the yield of the region obviously would be increased. To this end, agronomists have begun to prepare a

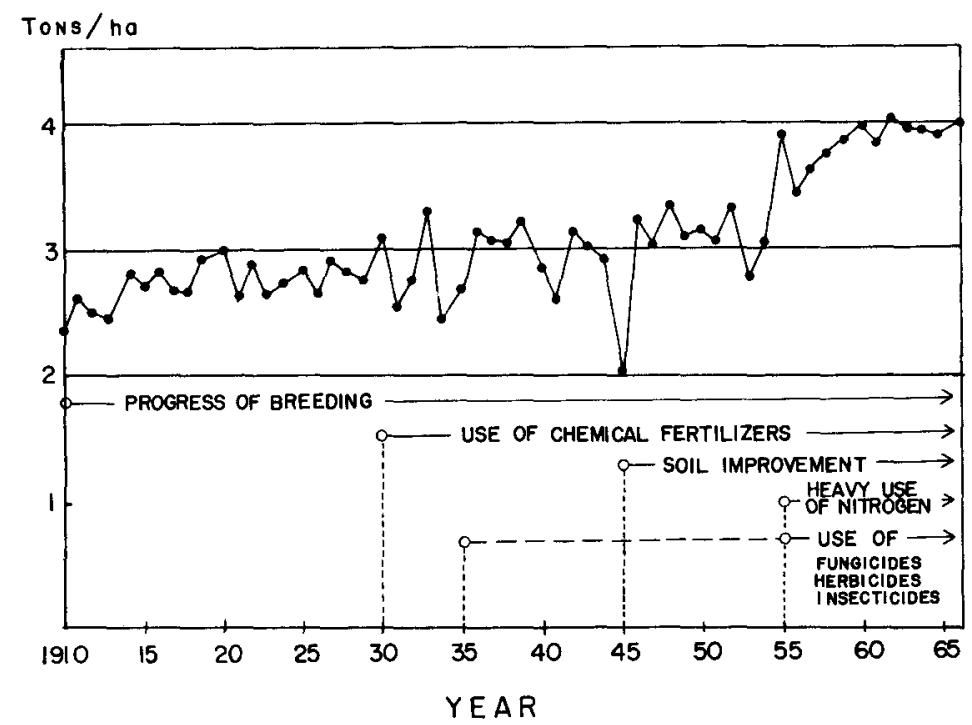

Fig. 2-1-Rice yields in Japan, 1910-1940. 
Table 2-2-Yield (metric tons) of grains in some countries 1956-1958 (FAO).

\begin{tabular}{lcc}
\hline Country & $\begin{array}{c}\text { Yield of grain, } \\
\text { tons /ha }\end{array}$ & $\begin{array}{c}\text { Fertilizer use, } \\
\mathrm{kg} / \mathrm{ha}\end{array}$ \\
\hline Taiwan & 2.857 & 163.4 \\
Switzerland & 2.895 & 169.2 \\
Belgium & 3.229 & 337.1 \\
Netherlands & 3.314 & 438.6 \\
Denmark & 3.462 & 130.0 \\
Japan & 3.633 & 257.4 \\
\hline
\end{tabular}

Table 2-3-Yield (metric tons) of brown rice in some agricultural experiment stations in Japan.

\begin{tabular}{lcccc}
\hline Location & $\begin{array}{c}\text { Latitude } \\
\text { north }\end{array}$ & $\begin{array}{c}\text { Annual mean } \\
\text { temperature, }\end{array}$ & $\begin{array}{c}\text { Yield } \\
\text { brown rice } \\
\text { tona/ha }\end{array}$ & Year \\
\hline Hokkaido & 43.03 & 7.7 & 7.79 & 1967 \\
Tohoku & $\mathbf{3 9 . 2 7}$ & 11.4 & 7.55 & 1958 \\
Hokuriku & 37.06 & 12.5 & 7.45 & 1962 \\
Konosu & $\mathbf{3 6 . 3 5}$ & 15.7 & 8.07 & $\mathbf{1 9 5 9}$ \\
Chugoku & $\mathbf{3 4 . 5 1}$ & 15.9 & 7.81 & 1959 \\
Shikoku & 34.15 & 15.2 & 8.15 & 1959 \\
Kyushu & 33.12 & 15.7 & 7.62 & $\mathbf{1 9 6 0}$ \\
\hline
\end{tabular}

blueprint on how average farmers under normal conditions can obtain a definite yield per hectare. What figure shall we take for yield, 3 tons/ha, 5 tons/ha or 6 tons/ha? Average yields of grain of some countries are shown in Table 2-2. Based on these data, a yield of 6 tons $/$ ha is almost twice the average grain yield in certain developed countries with intensive agriculture.

Yields of brown rice at various Agricultural Experiment Stations in Japan (Table 2-3) are considerably better than the country-wide grain yields shown in Table 2-2. These yields (7.45 to 8.15 tons/ha) are such that a goal of 6 tons/ha seems to be reasonable.

The yield of brown rice from 10 ares $\left(1,000 \mathrm{~m}^{2}\right)$ can be expressed theoretically by the following equation:

Yield (of brown rice) $=$ No. of spikelets per $\mathrm{m}^{2}$ (No. of ear $/ \mathrm{m}^{2} \times$ No. of spikelets/ear) $\times$ percentage of spikelets bearing a ripe grain $x$ average weight per grain (based on 1,000 grains) $\times 1,000$.

For example, the following combination of yield components would result in a yield of $600 \mathrm{~kg} / 10$ ares ( 6 tons $/ \mathrm{ha}$ ):

$600 \mathrm{~kg} / 10$ ares $=32,000$ spikelets $/ \mathrm{m}^{2}\left(400 \mathrm{ears} / \mathrm{m}^{2} \times 80\right.$ spikelets $/$ ear) $\times 0.85$ (fraction of spikelets with a mature seed $) \times 0.022 \mathrm{~g}(22 \mathrm{~g} / 1,000$ grains $) \times 1,000$.

It would seem that this blueprint would not be too difficult to follow. The number of spikelets on one ear and the weight of 1,000 grains is 
Table 2-4-Analysis of the yield of rice in northern Japan.

\begin{tabular}{|c|c|c|c|c|c|}
\hline Location & $\begin{array}{l}\text { Name of } \\
\text { variety }\end{array}$ & $\begin{array}{c}\text { No. of } \\
\text { plants } / \mathrm{m}^{2}\end{array}$ & $\begin{array}{c}\text { No. of } \\
\text { ears } / \mathrm{m}^{2}\end{array}$ & $\begin{array}{l}\text { Percentage } \\
\text { of } \\
\text { effective } \\
\text { tillers }\end{array}$ & $\begin{array}{l}\text { Yield, } \\
\text { tons /ha }\end{array}$ \\
\hline Hoddaido & Yukara & 21.8 & 545 & 66.0 & 7.79 \\
\hline Tohoku & Norin-17 $\left(\frac{\text { A.E.S }}{\text { No-17 }}\right)$ & 30.3 & 436 & 91.2 & 7.55 \\
\hline Hokuriku & Manryo & 22.7 & 529 & 75.4 & 7.45 \\
\hline
\end{tabular}

attributed to the variety. There are many varieties presently available that fulfill the condition of having at least 80 grains/ear and a 1,000 grain weight of $22 \mathrm{~g}$. If we want to harvest $600 \mathrm{~kg} / 10$ ares from such varieties, it is necessary to have 400 ears $/ \mathrm{m}^{2}$, with $85 \%$ of the spikelets having mature seeds. In a good year, it is not very difficult to have $90 \%$ matured grains. However, in the case of a poor year (less sunshine and a cool summer), this declines to $80 \%$. Therefore, $85 \%$ is a rather reasonable figure to put into the equation. The 400 ears $/ \mathrm{m}^{2}$ might be achieved by using a plant spacing of 20 by $20 \mathrm{~cm}$. With the resulting density of 25 plants $/ \mathrm{m}^{2}$, each plant would need an average of 16 effective tillers to produce 400 ears $/ \mathrm{m}^{2}$. This is not difficult to achieve, as shown by actual data (Table 2-4) obtained in the northern part of Japan where cultivation of the rice plant is supposed to be the most difficult in the nation.

In summary, then, to obtain 6 tons/ha, we need

1) 25 plants $/ \mathrm{m}^{2}$,

2) 16 effective tillers/plant,

3) 80 spikelets/ear,

4) $85 \%$ of spikelets with mature grain, and

5) $0.022 \mathrm{~g} /$ seed.

When weather conditions are not extremely poor, the above blueprint can be implemented using the ordinary varieties which are widely cultivated in Japan. The application of fertilizer, however, requires some skillfulness. I wish to come back to the matter of fertilizer application a little later, and it will be discussed in greater detail by Drs. Murata and Chandler in subsequent papers.

\section{ENGINEERING FOR HIGHER YIELDS}

How can the barriers against yields higher than 6 tons/ha be broken? I shall discuss this question from several points of view.

\section{A. Plant Type}

When the nutrient supply is the limiting factor for crop growth, the problem of plant type will not occur in connection with the efficiency of utilization of solar energy. However, when the supply of fertilizers is sufficient, and the price of fertilizers is low compared with the price 


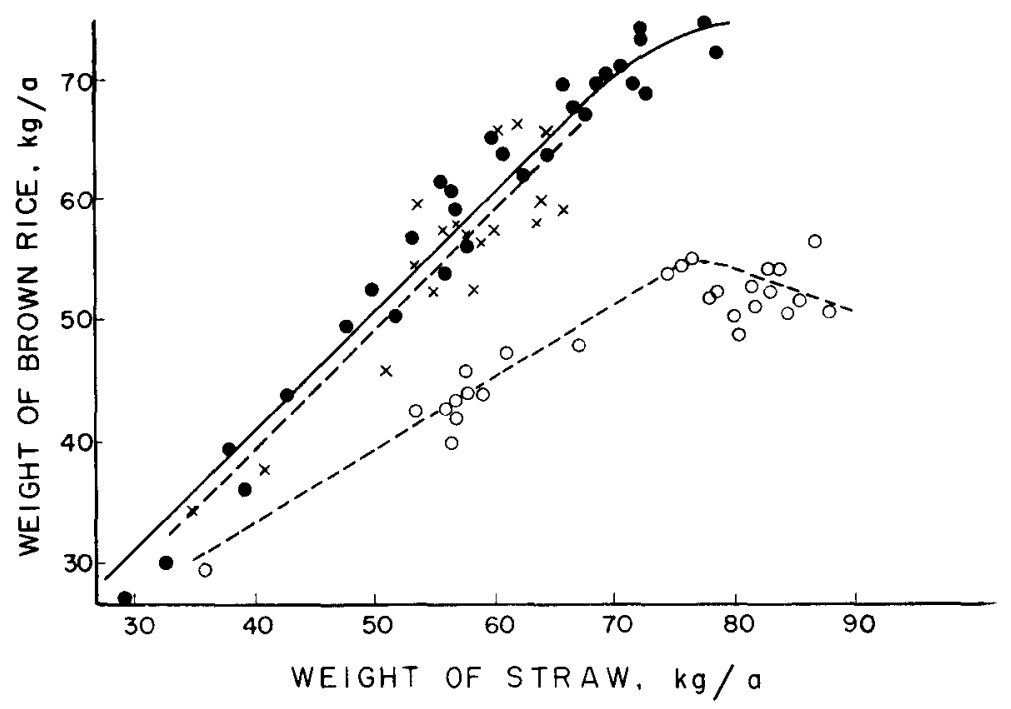

Fig. 2-2-Yields of brown rice and straw.

of crops, the concept of diminishing returns is encountered with respect to the value of added increments of fertilizer. Thus, in the case of the rice plant, the phenomenon shown in Fig. 2-2 is generally observed. of course, it is an illusion to say that fertilizer itself will produce crops, and that crop yield depends solely on the amount of fertilizers supplied. Fertilizers are only lubricants to promote the formation of $-\mathrm{C}-\mathrm{C}$ - chains.

Fundamentally, the ability to accept and transform solar energy controls the yield. Recently, this concept has prevailed among plant physiologists, and many outstanding reports have been published in Harvesting the Sun-Photosynthesis in Plant Life (A. San Pietro, F. A. Greer, and T. J. Army, 1967. Academic Press, Inc., New York), and also in the reports of the International Rice Research Institute. Accordingly, it is not necessary to dwell extensively on this problem; it will be enough to present some examples of the change in plant type in rice.

As shown in Fig. 2-3, the plant type of leading varieties propagated in Kokkaido, the northern limit area of rice cultivation in Japan, has changed considerably since 1890 . The improved yields obtained since 1935 are associated with decreased plant height and increased numbers of effective tillers. The newer varieties respond more dramatically to nitrogen fertilizer than do the early varieties (Fig. 2-4).

For any variety, decisions on the density of plant population which will produce higher yields must be considered from the standpoint of leaf arrangement and Leaf Area Index (LAI). It may be supposed that an optumum LAI will produce a maximum yield.

The number of leaves on the main stem is rather fixed. For instance, in the rice plant, the number of leaves on the main stem is 13- 


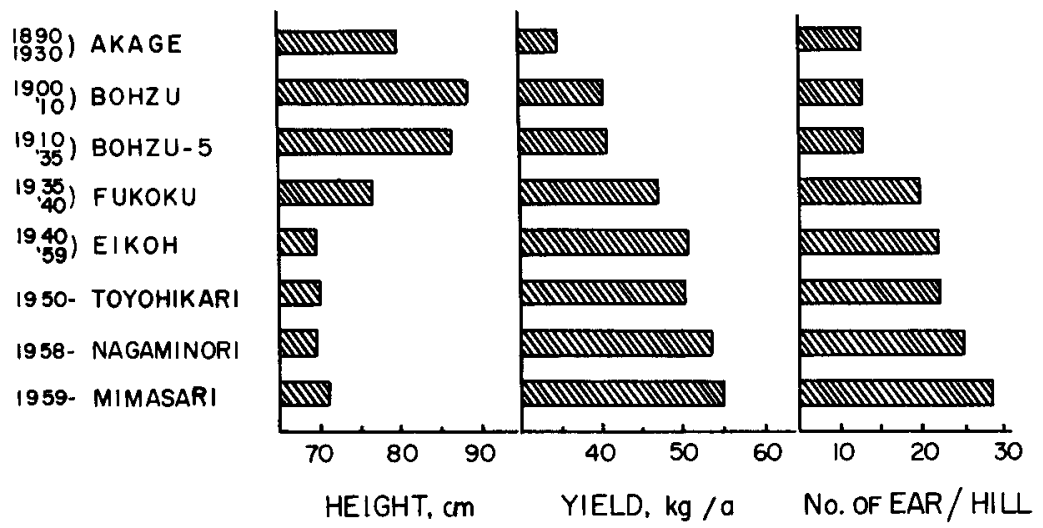

Fig. 2-3-Height, yield, and ears per hill for rice varieties grown in Hokkaido, Japan since 1890 .

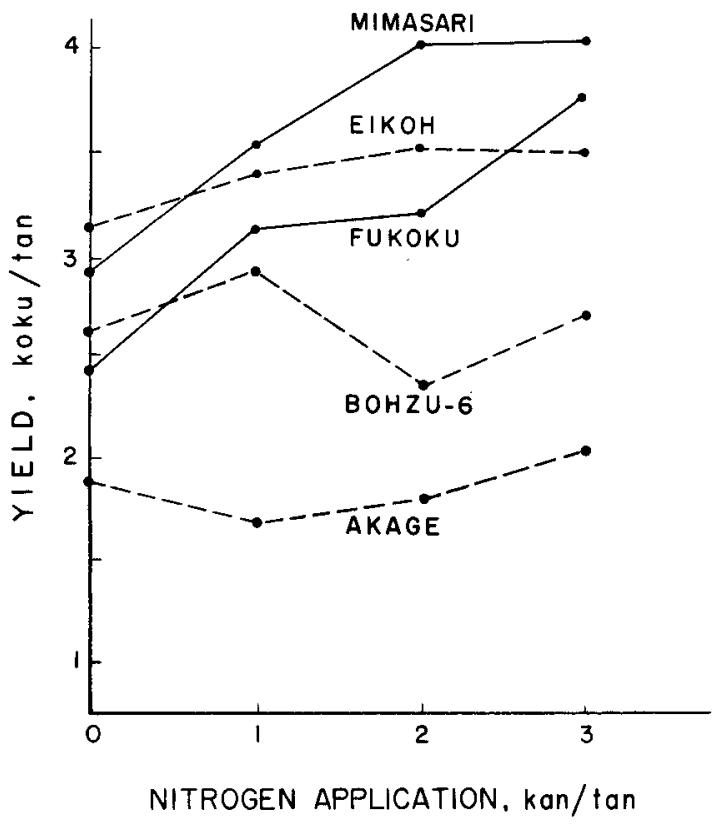

Fig. 2-4-Yield response of several rice varieties to nitrogen fetilization.

16 in Japan. Accordingly, when a rice plant population is fixed, the LAI will be governed to a great extent by the number of tillers. Therefore, "How to get an optimum LAI" becomes synonymous with "How to regulate the tillering number and position of tillers." Characteristics of tillering are varietal attributes. Theoretically, however, it is not difficult to imagine that the control of tillering may at some future time be possible through the use of agricultural chemicals. 


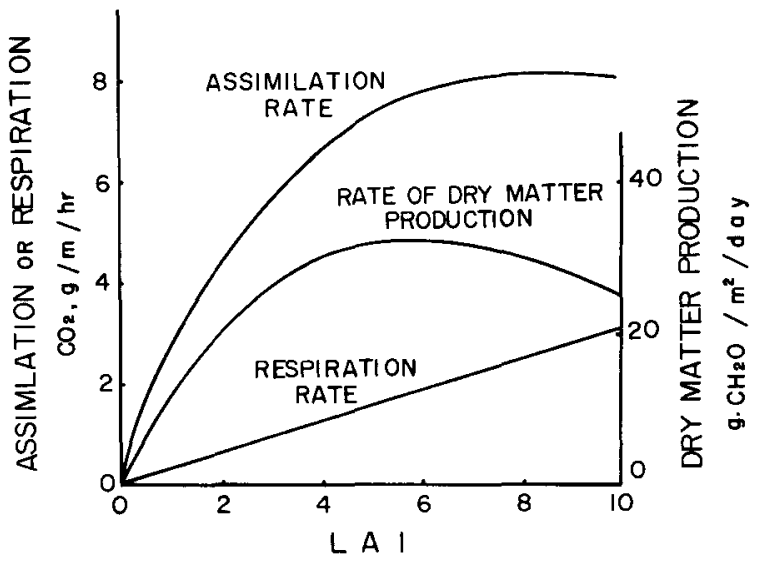

Fig. 2-5-Relationship of carbon assimilation, respiration, and dry matter production to LAI.

\section{B. Translocation and Respiration}

The second point is translocation and respiration. The latitude of Hokkaido University is about $43^{\circ} \mathrm{N}$, about the same as that of New York. Rice plants suffer some damage about once every 3 years, due to a cool summer. At such times, the total weight of straw is not much different from that obtained during an ordinary good year. The difference is in the weight of ear. Apparently the translocation of assimilates is retarded by the cool temperatures, though the reduced yield is partly due to lack of fertile pollen caused by damage during formation of the pollen mother cells.

To promote translocation, a supply of energy is needed. To provide or to create energy for translocation, respiration is indispensable. At the same time, it is generally recognized that the weight of crops is the algebraic sum of the assimilates produced by photosynthesis and lost by respiration. Thus, yield $=$ photosynehtsis - respiration (Fig. 2-5).

A simple way to obtain higher yields, it seems, is to make respiration as low as possible. Reducing respiration to a minimum would seem especially important in tropical climates where night temperatures are comparatively high and the loss of assimilates is much higher than in temperature regions where the yield of rice is comparatively high.

Several questions must be asked concerning respiration.

1) Is respiration always a negative factor in obtaining a higher yield?

2) Is a certain type of respiration indispensable for the growth of crops?

3 ) If the answer to question 1 is "yes," what kind of respiration has no significance for the growth of plants, how can we separate the respiration types, and how can the wasteful part of respiration be minimized?

Unfortunately, research on translocation and respiration in the field 
Table 2-5-Growth efficiency of rice plants in a community.

\begin{tabular}{lcc}
\hline \multicolumn{1}{c}{ Stage of growth } & $\begin{array}{c}\text { Growth } \\
\text { efficiency, }\end{array}$ & $\begin{array}{c}\text { Percentage of respiration } \\
\text { directly related to growth }\end{array}$ \\
\hline $\begin{array}{l}\text { Early stage } \\
\text { From booting stage }\end{array}$ & $(60)$ & $(100)$ \\
$\quad$ to flowering & 41 & 68 \\
$\begin{array}{l}\text { From flowering } \\
\quad \text { to milky stage }\end{array}$ & 36 & 60 \\
$\quad \begin{array}{l}\text { From milky stage } \\
\text { to complete ripening }\end{array}$ & 27 & 44 \\
\hline
\end{tabular}

of plant physiology has developed only rather recently and as yet much of it is not well recognized among agronomists. In the case of animal feeding, it is easy to determine so-called basal metabolism and to calculate the amount of nutrients necessary for this function. If we want to have a definite amount of milk, for instance, we can supply the nutrients which are necessary to have that amount of milk in addition to the requirements for basal metabolism. In the case of rice plants, when the growth of a new leaf is completed, we may assume that the respiration of that leaf corresponds to basal metabolism. This value is found to be about $40 \%$ as great as respiration during the period when the leaf was under vigorous growth (or assimilation). Thus, we may conclude that respiration for growth is $60 \%$ of the total respiration of a rapidly growing leaf. If the growth efficiency at this stage is $60 \%, 40 \%$ of the energy consumed by respiration is for basal metabolism and $60 \%$ of that is the energy for assimilation of new materials.

This calculation is quite rough, and it will have to be subjected to more precise research in the future. Such calculations have been used by Dr. Tanaka, for example, in comparing growth efficiency and respiration at various stages of growth of the rice plant (Table 2-5). The data plainly show that the growth efficiency, in other words the percentage of respiration directly related to growth, decreases with the progress of growth. We can suggest many possible reasons for this and the effort to find the correct reasons will lead the way to obtaining higher yields.

\section{Techniques of Fertilizer Application}

Generally speaking, the yield of crops depends to a great extent upon the amount of fertilizer nitrogen supplied. As suggested by the data in Fig. 2-2, vegetative growth is considerably more responsive to nitrogen than is reproductive growth (grain yield). Accordingly, it is important to apply the nitrogen in such a way as to give maximum encouragement to reproductive growth.

The goal in nitrogen application is to apply adequate amounts to obtain (or to produce) a sufficient number of kernels as estimated previously (for instance, $30,000 \mathrm{kernels} / \mathrm{m}^{2}$ ), and to reduce the nitrogen supply after obtaining this number in order to prevent the growth of ineffective new tillers. Later, then, appropriate amounts of nitrogen 
can be applied to keep the upper three leaves always active, and thus to promote the ripening of grain. However, it is not very easy to accomplish this in practice, because plant growth will be influenced by climate, and the buffer action of soils also will make it difficult to deliver the nitrogen to the crop in a way synchronized to promote a high yield. Further research on split applications of nitrogen fertilizer is needed.

\section{Minor Elements}

For a yield of 6 tons/ha, the problem of minor element deficiency is not serious, except in special cases such as sandy or calcareous soils. However, if we want to realize an even higher yield, this problem becomes more important. At this stage, the problem is not only the presence or absence of minor elements, but also their interaction. Because space is limited oniy one illustration, the interaction between zinc and manganese, will be given. As shown in Fig. 2-6, the deficiency of zinc becomes more serious when the supply of manganese increases and vice versa.

\section{E. Soils}

When we have a particular crop variety which has an ideal plant type, from the standpoint of utilization of solar energy, and when the supply of fertilizers is abundant, the factors which control crop growth will be some properties of the soil. If the soil is deficient in a property that is essential for crop growth, then the crop yield will be limited by that property. In such a case, the soil is of great significance in influencing crop yield. To achieve higher yields, it is necessary to use large amounts of fertilizer. Ideal varieties must be responsive to fertilizers; that is, they must be capable of absorbing large amounts of fertilizers and of using the absorbed fertilizer in producing increased amounts of grain. Unfortunately, heavy applications of fertilizer can lead to significant increases in the concentration of the soil solution, and this situation can result in decreased vigor of root growth, as shown in Fig. 2-7. In this instance root growth has been inhibited almost completely in areas adjacent to the site of urea application. To obtain higher yields, plant physiologists have begun to pay keen attention to the character of the leaf and stem. We also need to pay the same attention to the character of the root system, and soils must be evaluated with respect to their ability to support and encourage good root growth.

We might say that two categories of agriculture exist in the world; one is soil-dependent agriculture and the other is fertilizer-dependent agriculture. In the former case, the standard of soil evaluation is the natural supply of nutrients, that is the potentiality of soil to provide its own nutrients to crops. Here, the definition, "soil fertility," is quite clear.

However, in the case of fertilizer-dependent agriculture, the power of the soil to supply nutrients becomes a rather minor factor. Rather, the ability of soils to absorb fertilizers and deliver them to crops, or 

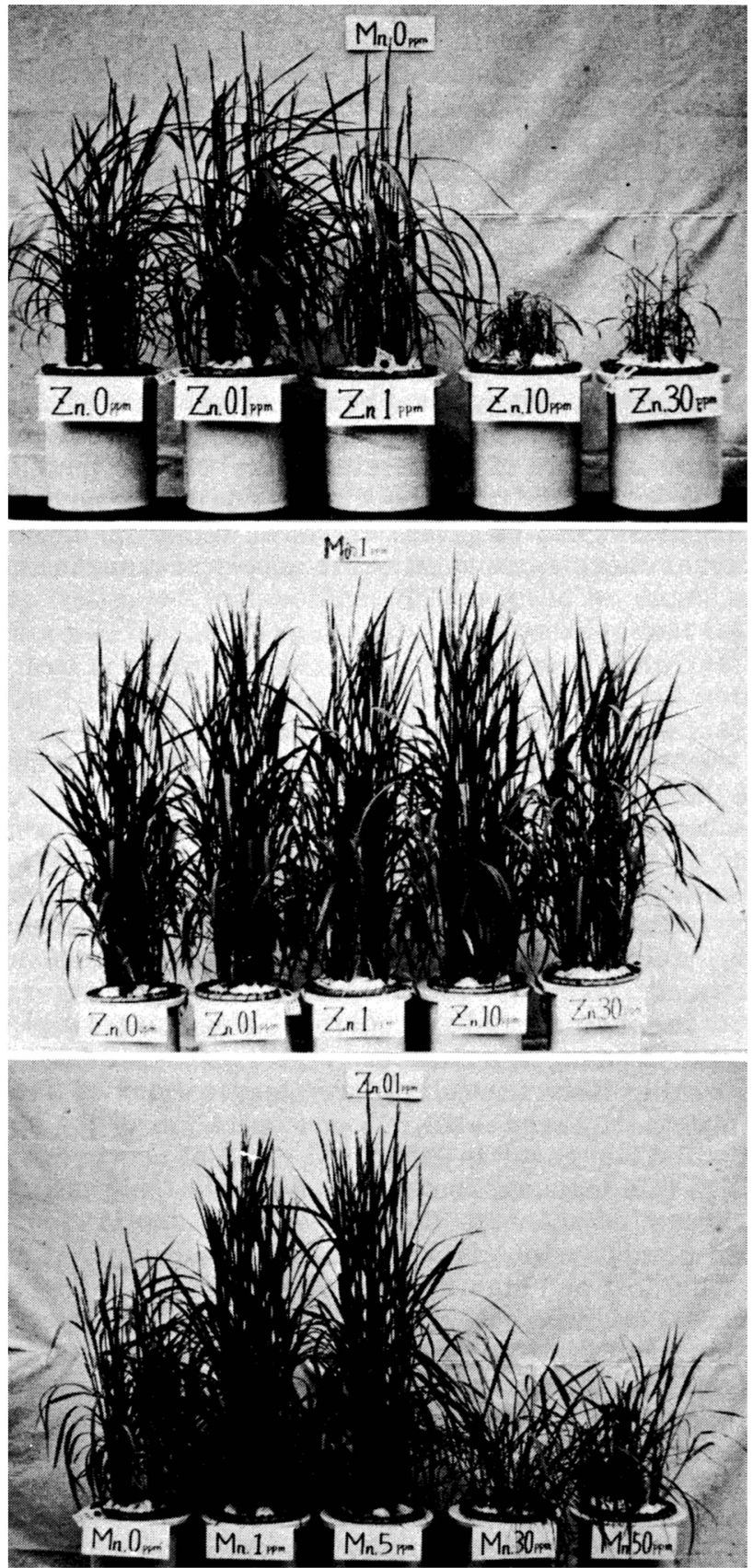

Fig. 2-6-Interaction of zinc and manganese. 


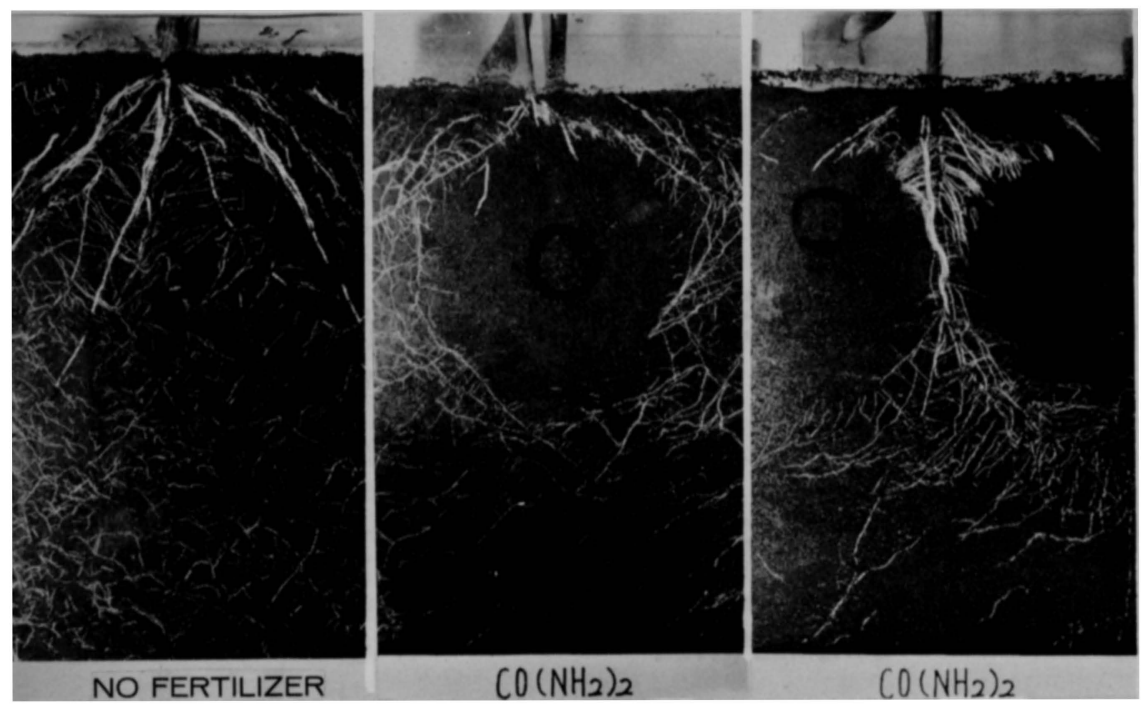

Fig. 2-7-Influence of urea application on root growth. Sites of urea application are shown by the circles.

the exchange capacity as well as the exchange energy of soils, and their buffer action, all play important roles in the production of higher yields. Also, certain physical and biochemical soil properties promote vigorous growth of roots, and others retard root growth. These factors must be taken into consideration in soil evaluation.

Clearly, in the case of fertilizer-dependent agriculture, the concept of soil fertility must approach the concept of "soil productivity." The methods of soil evaluation, and the approaches commonly used in research on soils, must be re-examined.

\section{CONCLUSIONS}

Just as "Rome was not built in a day" a higher yield of crops also will not be obtained in a day or two. It requires integration of agricultural sciences, techniques, education and extension.

When crop yields are low, for instance 1 ton/hectare, it is not difficult to bring them up to 2 tons/ha. But, when the yield of crops is comparatively high, for instance 4-5 tons/ha, it will be quite difficult to make further rapid progress.

However, the record shows that progress can be achieved. The purpose of this paper is not to give a final solution, but to point out problems to be further considered. I would appreciate having these problems discussed, and I hope that such discussion will lead to further progress.

The sciences of crop physiology and plant nutrition are vital in improving the world's supply of food; thus, they play an important role in bringing peace to the world. 